\title{
Designing an Interactive Multimedia Learning System for the Children of Primary Schools in Jordan
}

\author{
Sawsan Nusir \\ CIS Department \\ IT \& CS Faculty \\ Yarmouk University \\ Irbid - Jordan \\ sawsan_n@yu.edu.jo
}

\author{
Izzat Alsmadi \\ CIS Department \\ IT \& CS Faculty \\ Yarmouk University \\ Irbid - Jordan \\ ialsmadi@yu.edu.jo
}

\author{
Mohammed Al-Kabi \\ CIS Department \\ IT \& CS Faculty \\ Yarmouk University \\ Irbid - Jordan \\ mohammedk@yu.edu.jo
}

\author{
Fatima Shardqah \\ Computer center \\ Al al-Bayt University \\ Almafraq- Jordan \\ fatoomati@yahoo.com
}

\begin{abstract}
With the introduction of the Internet, and several new inventions and technologies especially in the communication and computer systems' field, there is a need to enhance teaching and educational methods through the utilization of those technologies which may improve the abilities of educators to present information in an interactive and media enhanced formats relative to traditional methods. This may help students or learners through offering them the information in channels and methods that can be easier to understand, deal with, and retrieve.

Multimedia technologies and applications are probably one of the most exciting innovations in the age of information evolution. They helped and got help from the Internet and other communication and computer inventions. Multimedia has the potential to create high quality learning environments, with the capability of creating a more realistic learning context through its different media. It also helps allowing a learner to take better control of the classroom especially when the class size is large.

This study aims at proposing and evaluating the possibility of enhancing the early education system with multimedia technologies. A program is developed to teach students at young ages basic skills. A study is investigated to show the impact of the developed program on students' abilities to understand new knowledge or skills. While many may argue against or with such studies of evaluating the impact of a technology on learning compared to traditional education. In all cases, multimedia education offers an alternative to traditional education that can enhance the current methods and provide an alternative especially in some cases where teaching in educational methods is not applicable.
\end{abstract}

Keywords- Multimedia, interactive learning, ICT, animation

\section{INTRODUCTION}

The government of Jordan has been concerned about developing and reforming the education system. Similar to education systems around the world, the current education system in Jordan is facing many challenges. Probably one of the most important challenges is the quality of education.

Over the past four decades, Jordan has invested heavily in education and allocated an average of $5 \%$ of its gross domestic product on education. Furthermore, an impressive improvement has been made in terms of number of students enrolled in the different levels of education. Unfortunately, recent reports indicate that there are several improvements to be done regarding the quality control and assurance of education. Such problem is widely recognized by many circles. For instance, in a recent report by the World Bank (2008) it is made clear that the Jordanian educational system, like other educational systems in the Middle East and North Africa (MENA region), depends heavily on memorization, definition, knowledge of facts and concepts. It fails to concentrate on learning and the usage of new approaches or techniques that reinforce creative and critical thinking among students. Another indicator about the poor quality of education is the results of the well known international test of eight graders in mathematics. The average math score for 21 countries in the MENA is 401. Though Jordan score is above the regional average but significantly below that of East Asia (466). It is also below the international average of 489 .

Recently technology has a significant impact on the educational system. Drucker stressed the idea that new technologies will force us to shift from teaching to learning [25]. Research into teaching and learning with new technologies is currently a very dynamic, high- 
profile and relevant area of educational enquiry [4].

Multimedia technology is probably one of the most exciting innovations in the information age. The rapid growth of multimedia technologies over the last decade has brought about fundamental changes to computing, entertainment, and education [26].

Multimedia has the potential to create high quality learning environments. With the capability of creating a more realistic learning context through its different media and allowing a learner to take control, interactive multimedia can provide an effective learning environment to different kinds of learners [3].

\section{DEFINITIONS}

Multimedia. Multimedia refers to computer-mediated information that is presented concurrently in more than one medium. It consists of some, but not necessarily all, of the following elements: text; still graphic images; motion graphics; animations; hypermedia; photographs; video; and audio, i.e., sounds, music, and narration. Multimedia can support multiple representations of the same piece of information in a variety of formats. This has several implications for learning.

Interactive Multimedia. By Interactive multimedia, educators unusually refer to the using of multimedia and Information Communication Technology (ICT) equipments to offer an effective dialog between the instructor and the students in comparison with traditional methods of teaching which may lack such interactivity. However, supporters of traditional methods of teaching argue that the face to face communications can be more interactive.

Multimedia and Education. The advancement of technology has made significant impact on the evolvement of teaching methods from traditional face-to-face teaching to Computer-Based Learning (CBL) or- elearning systems in all levels of education. Modern education and communication environments can offer alternative ways in the learning process.

Multimedia has been widely used in educational technologies. It is also expected that future will see more of the utilization of such tools in education. Some argue that multimedia and e-learning tools can be used as a supplement to traditional classes (and not as replacement). Using interactive multimedia in the teaching process is a growing phenomenon. Multimedia plays a very important role in assisting students in learning processes. Therefore, it can be concluded that the Multimedia enhance and enable students to learn in a more effective way.

More efforts are needed to create new programs using multimedia elements and multimedia authoring tools to fulfill a contentrich learning software and courseware to provide to different students.

\section{THEORETICAL BACKGROUND}

The roles of interactive multimedia and its effectiveness have been the subject of many studies. This section intends to shed light on the main works in this area.

User Interactivity is a major feature of well-designed multimedia courseware. In fact, researchers have shown that an interactive learning environment can generate effective instruction and learning system $[2,6,7]$

In different researches by Mayer, results indicate that using multi-modal instruction is more effective than using any single mode [27, 28]. In other words, this finding demonstrates that media do impact learning, through the instructional possibilities that they enable. For example, based on Mayer's research, one could state that when used appropriately, the video medium should be more effective than radio, since the latter cannot provide visual information. The presentation of ideas in visual form has proven to be particularly important as it critically helps the educational process.

In a review by various researchers of studies that have investigated the effectiveness of multimedia in learning suggested that the people who used computer-based multimedia instruction performed better in terms of test scores, compared to those who received instruction through traditional classroom lectures.

Bayhan et al explored the use of computers at home to develop mathematical ideas and reported that there were considerable potential for computer games to support such learning [29].

Stitch 2003 study shows that the use of animation in teaching cell biology and all fields of biology are beneficial. It was found that scalable interactive animation with hot keys and rollover help to enhance the learning in effective way. Animated illustration accompanied with audio, video, and kinetic are much better to the cell biology learners than static illustrations [9]. 
(Cronje et al investigated the differences of mental models of learners and designers. The study was based on six high school students ( 3 males \& 3 females) attempting to learn principles of electricity [8]. The students were selected in a way that reflects three levels (i.e. weak, middle, and good) for each gender. The results revealed considerable differences between the mental models of learners and designers. The free navigation of the multimedia learning program helps good students to accelerate their learning, while weak students are lost [1].

(Holzinger et al study addressed the effects of using simulation to teach complex physiological models to 96 students of college of medicine. They found that the effectiveness of the designed simulator and the conventional text lessons are equivalent. Using additional guidance to the designed simulator helps to improve the learning process [2].

The Kamat et al.'s 2009 project is based on the results of test on a number of interactive multimedia packages for grade I to IV. These multimedia packages are usually used for subjects like science, mathematics, geography, history ...etc. It was concluded that interactive multimedia is much better than traditional educational system, which depends on classrooms and lecturers using chalk and talk [3].

Kay aimed at finding whether gender affects the use of an interactive classroom communication system (ICCS), which used extensively in secondary schools these days. The study examined student involvement, assessment, and perceived learning of a sample of 659 secondary school students, which equally divided between males and females. The comparison reveals that male students are more significantly positive than their counterpart's female students [4].

Computer games can be used as a teaching and learning tool. Ke's study aimed to find the effect of educational computer games on the 4th and 5th graders' to learn mathematics. To achieve this goal the study tested the effect of educational games on cognitive math achievement, meta-cognitive awareness, and positive attitudes toward math learning. Results revealed that educational computer games help to attract students towards learning math during the first five weeks, but it has no effects on cognitive math achievement, and meta-cognitive awareness [5].

Liu at al. study results confirm previous results stating the positive effect of media richness within e-learning educational systems on the user's intention to use such systems. Elearning systems that present its materials using text, audio, and video stimulating a higher perceived usefulness (PU) and concentration than their counterparts which used text only, text and audio, or text and video, or audio and video[6].

E-learning should not be a replacement to the traditional learning, but an improvement to the efficiency of learning process. Academic establishments adopt a number of learning strategies to enrich learning process, and this is called blended learning. The experiments show that retention rate is $10 \%$ and $80 \%$ for learning by reading and practicing respectively [16].

Many studies have found that the effectiveness of online teaching modules is equivalent to traditional way of teaching. Moneta et al. explored the effectiveness of interactive multimedia online courses versus the traditional lecture based on studying an introductory computing course. It was concluded that well designed e-learning modules have its pros, but could not prevent the cons found in traditional modules [10].

Evans et al. tried to find the effects of adding interactivity to computer-based learning packages of Business and Management on a small sample of undergraduate students (22 males, and 11 females). The sample was randomly divided into two groups, in order to test the effect of interactivity versus the noninteractive modules. The results reassert the positive effects of using visualization to improve the depth of learning and understanding. Also the results show that gender has no effect on learning [11].

Due to the lack of sufficient proficient English language teachers in Philippines public schools, alternative ways are used to bridge this need. Atienza et al. and the department of education at the University of the Philippines created handheld electronic reader that helps students to pronounce English words correctly, and to supplement English materials for third grade students at Philippines elementary schools. The electronic reader was used to monitor, test and evaluate the performance of 300 students. Results show that the electronic reader improves significantly the learning process [12].

Recent studies attempted to evaluate the cognitive load (CL) to learn and understand online, multimedia curriculum. These studies concluded that as the interactivity of the presented materials increase, the CL decrease. For instance, Chang et al. evaluated CL during four weeks to learn Web-based materials about global warming by 105 (24 males, and 81 females) 11th grade students from an academic senior high school in Taiwan [13]. Gender differences were statistically significant, where 
males are overloaded with reading scientific articles, while females are engaged with chat rooms and search activities. Scientific articles, online notebooks, flash animations and online tests, might need high mental effort, while chat rooms, videos, and interactivity need low mental effort.

Most of the E-Learning materials designed linearly forcing its users to sequential learning, so that all users are forced into same path pedagogy regardless of their experience and their needs. So Robberecht study asserts the need for designing interactive nonlinear elearning educational systems. Those are intelligent enough to dialogue with the learners according to their actions and responses. Also the e-learning educational systems should attract different learners regardless of their experience [14].

Well designed Interactive multimedia elearning systems can attract the learners to posses more information. Active engagement is important factor towards improving learning process. Said attempts to lay down a foundation of design model of interactive multimedia e-learning system which offers active engagement [17].

\section{DESIGN AND DEVELOPMENT}

Designing an interactive educational multimedia need to present the learning material in an adequate form and need to provide the facilities to enable and process learner activities. In designing new technologies for children, researchers of Human-Computer Interfaces (HCI) have discovered that children have unique likes, dislikes, and needs that are often different from those of adults. In addition to that it is important to know how interactive multimedia elements are used in teaching and learning math.

One of the most important issues in designing a course material is how to transfer the course contents to students via a combination of text, graphics, sound and animation. The Use of multi-sensing communication can lead to better learning results, increasing the motivation for students to learn, achieving larger volumes of knowledge transfer and more attractive ways in presenting educational content.

Stemler mentioned that "Educators should have access to appropriate ways to design software packages that will take advantage of multimedia capabilities without losing the focus on the user's needs or the content being presented" [30].

\section{PURPOSE OF THE STUdY}

This study aims at:

I. Finding the differences (if any) in achievements of first grade children in arithmetic mathematics, between those students who use the traditional learning approach and those who use the interactive multimedia approach

II. Find the association (if any) between gender of first grade children and their levels of achievement in arithmetic mathematics by using the traditional learning approach and the interactive multimedia approach.

III. Identifying the strengths and weaknesses in the traditional and newly proposed system.

IV. Propose software programs that can help students learn different school subjects using the multimedia interactive learning system.

V. Propose new course contents for selective years and subjects in preliminary education in Jordan. Those newly proposed course will take into account the current material along with introducing it to the students in the new interactive multimedia format.

VI. Study the possibility of creating interactive games that can be part of the study material which introduce information materials to low grade students in an attractive format.

VII. Propose interactive courses to deal with students of special needs such as students with hands disabilities, visual, or hearing impairments.

\section{PROBLEMS WITH TRADITIONAL EDUCATION SYSTEM}

In this section, we will discuss some problems with the current traditional educational system in Jordan. Those problems may not be always true. Those problems are also related to the proposed enhancements and do not focus on other issues such as the international quality standards for educational systems.

A major problem with the current educational system in Jordan and many other countries in the region is the large number of students per classes. This problem arises as a large percentage of population in these countries is usually young or in the age of schools and universities, besides those who enrolled in vocational institutions, and universities. This makes a serious stress on the educational system that includes the classes, instructors, and students. 
Large classes may cause several problems for instructors. They are usually harder to control. It is not easy for the instructor to ensure that all students are concentrating on the course material. It is not easy also for students of large classes to focus especially where teaching maybe traditional using the board or through directly listening to the instructor. It will take time for instructors to list the number of students to record those who are absent, ...etc. Instructors will also have a hard time dealing with students on the individual basis and interact with them, answer their queries, or evaluate their understanding.

Large classes imposed a further headache on the instructor to manage his/her exams. Another problem with the large size is the instructor problem ability to write and correct exams. It may decrease chances to give quizzes, assignments, and any extra works. Instructors will hardly have time to grade main exams.

Current traditional educational systems are also incapable of dealing with students of special needs and disabilities. Students who have visual, or hearing problems may not be able to see or hear well the class material especially when class size is large.

In the age of information evolutions, students are equipped with cell phones, laptops with wireless internet and probably some other high tech gadgets. It maybe sometimes boring and uninteresting to present to them the course material on a board or direct rehearsal. The educational system may need to utilize and compete with the new Information and communication technologies and benefit from them. There are lots of possibilities of such utilization such as: using simulation and animation to present some of the complex boring problems in a more appealing format. Such techniques maybe particularly useful for teaching kids within primary schools with early ages.

Rural areas are usually faces the problem of shortages in the number of teachers in their schools having problems of certain instructors' qualifications. Usually teachers Such instructors may not be willing to teach in rural areas. Traditional educational systems may not provide a solution to this problem, but new technologies can provide a solution to this problem by recording different teacher courses or through an e-learning system.

A new interactive educational system may provide solutions to the problems in the traditional educational systems.

VII. MEthodology
The population of the study consists of all first grade children enrolled at Yarmouk University Model School. First grade students are divided randomly into two sections (groups). The researchers designed and developed a multimedia program that covers two topics from math curriculum (The Ministry of Education curriculum). Table 1 shows the research procedures.

\begin{tabular}{|c|c|c|c|}
\hline & & Group 1 & Group 2 \\
\hline \multirow[t]{2}{*}{ Step1 } & \multirow[t]{2}{*}{ Topic1 } & $\begin{array}{l}\text { Lecture / } \\
\text { Traditional } \\
\text { approach }\end{array}$ & $\begin{array}{l}\text { Interactive- } \\
\text { multimedia } \\
\text { approach }\end{array}$ \\
\hline & & $\begin{array}{l}\text { Text-based } \\
\text { Quiz }\end{array}$ & $\begin{array}{l}\text { Computer- } \\
\text { based Quiz }\end{array}$ \\
\hline \multirow[t]{2}{*}{ Step2 } & \multirow[t]{2}{*}{ Topic2 } & $\begin{array}{l}\text { Interactive- } \\
\text { multimedia } \\
\text { approach }\end{array}$ & $\begin{array}{l}\text { Lecture / } \\
\text { Traditional } \\
\text { approach }\end{array}$ \\
\hline & & $\begin{array}{l}\text { Computer- } \\
\text { based Quiz }\end{array}$ & $\begin{array}{l}\text { Text-based } \\
\text { Quiz }\end{array}$ \\
\hline
\end{tabular}

As can been noticed from Table 1, the research consists of two steps. In the first step, the first group will be taught traditionally approach, whereas the second group taught the same materials of the first group using the newly developed multimedia program. Each group is given a test. The first will be subjected to a traditional text-based quiz, while the second group will be given a computerbased quiz. In the second step of the research procedure the two approaches will be reversed.

\section{METHODS AND PROCEDURES}

In designing the tool used in the present research the following procedure were utilized:

I. An interactive multimedia program was built to cover one of the main topics (fractions principles) in mathematics for Grade 1 students that are usually covered in the textbook adopted by the Ministry of Education. This program was developed by using Adobe Flash CS3 as an authoring tool.

II. Different multimedia elements were used to deliver the needed information (text, images, sound, and animation) with interactive and retroactive (feedback) features implemented within a user- friendly interface. III. The students were allowed to interact with the interactive multimedia lesson for a maximum of 30 minutes followed by a computerized short test.

Screens Design Features 
The Interactive Multimedia program was designed and implemented by integrating different multimedia elements. Special attention was given to the interactivity "user control", vivid colors, animation, and using a common cartoon characters usually kids like to make it more attractive and different than traditional way.

- Main Screen

It can be seen in Figure 1 that the main screen contains buttons that linked to the basic components of the selected material. These buttons were designed by using a combination of different elements. Figure 1 shows the main user interface for the program developed.

- Text: a clear and easy to read font size and style was utilized. Bailey et al suggested that no more than two or three types and sizes of fonts be used per screen [31]. Garner adds that one font per screen be used unless certain material needs to be emphasized. In this case, varying the size and font of text can be used to attract attention [32].

- Graphics: As shown in figure ? one of the most cartoon charters the kids prefer (Tom \& Jerry) associated with simple drawings to represent the topic.

- Sound: A kid's voice to the main buttons was attached. When the child rollover any of these buttons he/she will hear the title of the button.

- Animation: in addition to the sound attached to each button the button will be little bet larger when the child rollover the button.

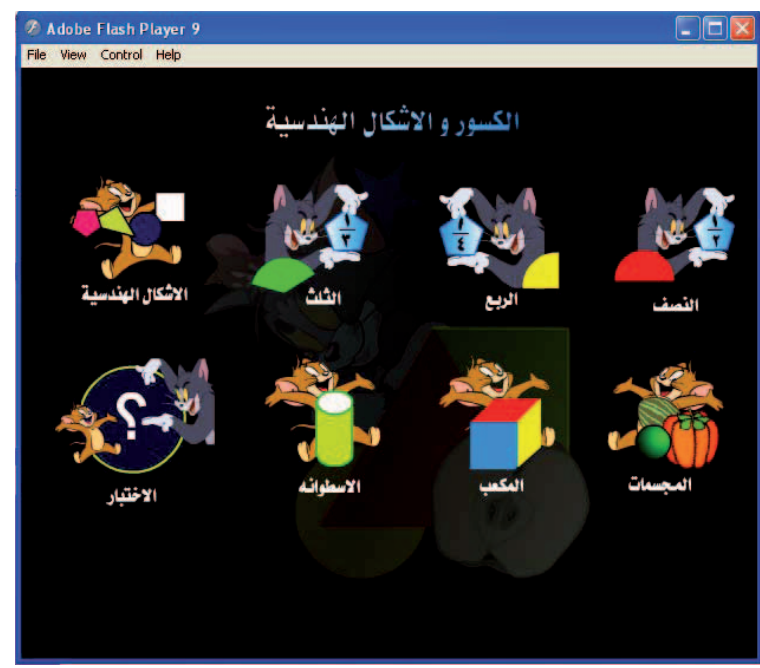

Figure 1. The main user interface for the developed program
In order to evaluate the impact of using multimedia interactive educational tools on education, a case student is designed and executed on two classes from Yarmouk University model school. Each group is further divided into two groups. The same educational material which was about teaching basic math skills is taught through the traditional educational methods along with the multimedia interactive one. In order to reduce possible biases in the study, classes were selected as they are without any rearrangement or reordering of the students in the 4 classes selected for the studies (two classes for each method). At the end of the educational session, a simple math exam is conducted on the two teams. Table 2 shows the summary of the results.

TABLE II SUMMARY OF THE RESULTS

\begin{tabular}{|c|c|c|}
\hline & Multimedia & Traditional \\
\hline $\begin{array}{l}\text { No of } \\
\text { Students }\end{array}$ & 123 & 122 \\
\hline Average & 8.7 & 7.833333 \\
\hline
\end{tabular}

\section{CONCLUSION AND FUTURE WORK}

In this study, a small math program is developed for students at young age to evaluate the impact of interactive learning on students' abilities to improve their learning skills. As explained in the paper, and despite the fact that results showed improvements in students learning skills, however, this is not a proposal for replacement of traditional education. Rather, interactive enhanced learning can provide a very useful alternative for traditional education especially in cases where it is not applicable to teach through traditional methods.

In future, a field study will be conducted on students of schools in Jordan to assess the effectiveness of using multimedia interacting systems with larger study or experimental groups.

The output results from the study will be investigated to see the strengths and weaknesses with the newly proposed system. Future improvements will be reevaluated using the same or different group of study. Eventually interactive educational materials will be proposed for certain courses or parts of courses.

IV. RESULTS AND ANALYSIS 


\section{REFERENCES}

[1] Clements, D., H. (2002) Computers in Early Childhood Mathematics, Contemporary Issues in Early Childhood, 3(2), $\quad$ pp. 160-181 http://dx.doi.org/10.2304/ciec.2002.3.2.2

[2] Harper, B. \& Hedberg, J. (1997) Creating Motivating Interactive Learning Environments : a Constructivist View. Paper presented at ASCILITE December 7-10 1997.

[3] Margie, J., Liu, M., (1996). Introducing Interactive Multimedia to Young Children: A case Study of How Two-Years-Olds Interact with the Technology. Educational Resources Information center

[4] Muller, D., Eklund, J., and Sharma, M., (2006). The future of multimedia learning: Essential issues for research. MUL

[5] Norhayati, A. M., \& Siew, P. H. (2004). Malaysian Perspective: Designing Interactive Multimedia Learning Environment for Moral Values Education. Educational Technology \& Society, 7 (4), 143-152.

[6] Sims, R. (1998) Interactivity for effective educational communication and engagement during technology-based and online learning in McBeath, McLoughlin \& Atkinson (eds) Planning for Progress, Partnership and Profit. Proceedings EdTech'98.

[7] Shinde J. (2003) Effectiveness of Multimedia CAI Package with reference to Levels of Interactivity and Learning Styles. Unpublished thesis, SNDT Women's University, Mumbai

[8] Cronje, J. C., \& Fouche, J. (2008). Alternatives in evaluating multimedia in secondary school science teaching. Computers \& Education, 51(2), 559-583.

[9] Holzinger, A., Kickmeier-Rust, M., Wassertheurer, S., Hessinger, M. (2009) Learning Performance with Interactive. Simulations in Medical education: Lessons learned from results of learning complex physiological models with the HAEMOdynamics SIMulator, Computers \& Education, 52(2), 292-301.

[10] Kamat, V. and Shinde, J. (2009). "Enrichment of the learning experience of rural children through interactive multimedia," The Pan-Commonwealth Forum on Open Learning.

[11] Kay, R.H., (2009). Examining gender differences in attitudes toward interactive classroom communications systems (ICCS). Computers \& Education, 52, 730-740.

[12] Ke, F. (2008). A case study of computer gaming for math: Engaged learning from gameplay? Computers \& Education, Volume: 51, Issue: 4, Pages: 1609-1620

[13] Liu, S. H., Liao, H. L., \& Pratt, J. A. (2009). Impact of media richness and flow on e-learning technology acceptance, Computers \& Education, 52(3), 599-607.

[14] Madden, M.; Chung, P.W.H.; Dawson, C.W. (2008) The effect of a computer-based cartooning tool on children's cartoons and written stories, Computers \& Education,51(2), 900-925.

[15] Pintrich, P.R. \& De Groot E. (1990). Motivational and Self-Regulated Learning Components of Classroom Academic Performance, Journal of Educational Psychology, 82, 33-40.

[16] Stith, B. (2004). Use of Animation in Teaching Cell Biology. Cell Biology Education, 3, 181-188.

[17] Moneta G.B., Kekkonen-Moneta S.S. (2007). Affective Learning in Online Multimedia and Lecture Versions of an Introductory Computing Course, Educational Psychology, Vol.27, No. 1, pp. 51-74.

[18] Evans, C., Gibbons, N.J. (2007). The interactivity effect in multimedia learning, Computers \& Education, 49 (4), 1147-1160

[19] Atienza R. O., Tai T. W.(2009). Interactive Electronic Reader to Support English Education, International Conference on Computer Technology and Development, ICCTD '09, 475 - 479.

[20] Chang C.-C., Yang F.-Y. (2010). Exploring the cognitive loads of high-school students as they learn concepts in web-based environments, Computers \& Education, 55 (2), 673-680

[21] Robberecht R (2007). Interactive Nonlinear Learning Environments, The Electronic Journal of e-Learning Volume 5. Issue 1, pp 59 - 68.

[22] Castilho-Weinert L.V. Lopes H. S. (2009). Computers in Physical Therapy Education: Interactive Multimedia Learning with MuStreT, Informatics in Education, Vol. 8, No. 2, 157-172.

[23] Shoniregun C. A. and Gray S.-J. (2003). Is Elearning Really the Future or a Risk, Ubiquity Journal, 4(10).

[24] Said, Normahdiah Sheik (2007). Towards a 'mode of engagement' Designing Multimedia Application for Children, Digital Learning, Volume III Issue 1, eASIA 2007.

[25] Drucker, P.F. (1999). Knowledge-worker productivity: The biggest challenge. California Management Review, 41, 79-41.

[26] Norhayati, A. M., \& Siew, P. H. (2004). Malaysian Perspective: Designing Interactive Multimedia Learning Environment for Moral Values Education. Educational Technology \& Society, 7 (4), 143-152.

[27] Mayer, R. E. (1997). Mulimedia learning: Are we asking the right questions? Educational Psychologist, 32(1), 1-19.

[28] Mayer, R. E. (2001). Multimedia learning. Cambridge, U.K. ; New York: Cambridge University Press.

[29] Bayhan, P., Olgun, P. \& Yelland, N.J. (2002) A Study of Pre-school Teachers' Thoughts about Computerassisted, Instruction, Contemporary Issues in Early Childhood, 3(2), pp. 298-303. http://dx.doi.org/10.2304/-ciec.2002.3.2.11

[30] Luann K. Stemler, Educational Characteristics of Multimedia: A Literature Review, Jl. of Educational Multimedia and Hypermedia (1997) 6(3/4), 339359.

[31] Bailey, H. J., and Milheim, W. D. (1991, February). A comprehensive model for designing interactive video based materials. Proceedings of the Ninth Conference on Interactive Instruction Delivery, 1991. Society for Applied Learning Technology Conference, Orlando, FL.

[32] Garner, K. H. (1991). 20 rules for arranging text on a screen. In R. B. Frantzreb (Ed.), Training and development yearbook 1991 edition. Englewood Cliffs, NJ: Prentice Hall. 